\title{
Influence of Tooth Bleaching on the Bonding Strength of Silorane-Based Restorative System
}

\author{
Influencia del Aclaramiento Dental en la Fuerza de \\ Adhesion del Sistema Restaurativo a Base de Silorano
}

Tamea Lacerda Monteiro*; Nayara Cristina Monteiro Carneiro*; Bárbara Catarina Lima Nogueira*; Esther Marina França Braga**; Mário Honorato Silva e Souza Júnior** \& Sandro Cordeiro Loretto ${ }^{* *}$

MONTEIRO, T. L.; CARNEIRO, N. C. M.; NOGUEIRA, B. C. L.; BRAGA, E. M. F.; SOUZA JÚNIOR, M. H. S. \& LORETTO, S. C. Influence of tooth bleaching on the bonding strength of silorane-based restorative system. Int. J. Odontostomat., 9(3):497-504, 2015.

ABSTRACT: Bleaching procedures can interfere on adhesive bonding of methacrylate-based restorative materials. After introduction of silorane-based composites, little information is available about this interaction. The objective is evaluate the influence of bleaching on enamel shear bond strength of silorane-based restorative system. Forty sound incisive bovine teeth were randomly divided into 04 groups $(n=10)$, being: $G 1$ (control) - not bleached + Clearfil SE Bond (CSEB)/Filtek Z250 (Z250), G2 (control) - not bleached + Silorane Adhesive (SA)/Filtek P90 (P90), G3 - bleached + CSEB/Z250; G4 bleached + SA/P90. The teeth were sectioned, had crowns included in a PVC rings, and the enamel surfaces gridded and polished with silicon carbide abrasive papers. G1 and G2 were stored in artificial saliva $\left(37^{\circ} \mathrm{C}\right)$, daily renewed, for a period of 04 days. G3 and G4 were exposed to 02 sessions of 38\% hydrogen peroxide (38HP), with 03 applications of 15 min in each session. Composite resin cylinders were built up on the enamel surfaces. Bonding procedures were performed according the manufacturer's instructions. After storage in distilled water for $24 \mathrm{~h}\left(37^{\circ} \mathrm{C}\right)$, the samples were submitted to shear bond test. Data were analyzed by two-way ANOVA and t (LSD) tests (5\%). Intra group comparison showed significant difference for Z250 after bleaching, but not for P90. Shear strength was significant lower for P90, despite bleaching procedures. In conclusion, $38 \mathrm{HP}$ bleaching had no influence on the enamel bond strength of P90, even though presenting lower bond strength than Z250.

KEY WORDS: tooth bleaching, composite resins, shear strength.

\section{INTRODUCTION}

Tooth bleaching is one of the most requested dental treatments by patients to improve the appearance of their smile. However, neither composites nor porcelain show significant color changes after bleaching treatments, and if restorations of this nature are present in aesthetically critical areas, they will need to be replaced (Lima et al., 2011; Swift \& Perdigão, 1998).

Several studies have shown that there is a decrease in bonding strength to bleached enamel/ dentin when adhesive restorations are performed directly after different bleaching techniques (Amaral et al., 2008; Nour El-din et al., 2006). This fact can be attributed to morphological and/or chemical changes in substrates, or even to the presence of residual oxygen in the inner dental tissues, which interferes with the polymerization reaction in adhesive systems and composite resins by inhibiting the generation of free radicals (Burgess \& Cakir, 2010; Weinmann et al., 2005). However, it should be emphasized that this information is derived from the use of methacrylatebased resin materials (Nour El-din et al.; Hussain \& Wang, 2010).

In this context, a new composite based on silorane with low polymerization shrinkage was introduced on the dental market, comprised of different monomers of conventional methacrylate-based resins and a unique adhesive system. The formation of polymers through the opening of silorane rings

\footnotetext{
* Departament of Restorative Dentistry, School of Dentistry, Federal University of Pará, Belém, Brazil.

" Postgraduate Program in Dentistry, School of Dentistry, Federal University of Pará, Belém, Brazil.
} 
decreases the shrinkage of this material, reducing the possibility of crack formation and microleakage at the tooth/restoration interface (Ilie \& Hickel, 2006; Weinmann et al.). However, the interference of bleaching treatments with regard to the bonding strength to dental substrates in this category of materials is still largely unknown (Lima et al.).

Thus, the aim of this study was to evaluate the influence of prior tooth bleaching, as performed by an in-office technique, on the adhesive bonding strength of silorane and methacrylate-based restorative systems to enamel.

\section{MATERIAL AND METHOD}

This study was approved by the Ethics Committee on Research with Experimental Animals of the Federal University of Pará (CEPAE/UFPA) (protocol number: 096/12). Forty sound bovine incisors were rinsed in tap water and stored in a $0.1 \%$ thymol solution for 1 week. After disinfection, they underwent prophylactic treatment with pumice paste, and were examined under a stereo magnifier (10X) to ensure that the specimens were free from cracks or defects in the enamel.
Next, the teeth were sectioned at cementumenamel junction (CEJ), and had their remaining crowns mounted in PVC rings with chemically activated acrylic resin. After, the buccal surfaces of the enamel were gridded and polished with silicon carbide abrasive papers (400 and 600) under refrigeration.

The materials used in this study are described in Table I, including the brand name (manufacturer), classification, composition, and batch.

The total sample was randomly divided into 4 groups ( $n=10)$, according to bleaching treatment performance and the adhesive system / composite resin used (Table II).

Control groups (1 and 2) were kept in artificial saliva at $37^{\circ} \mathrm{C}$ for a period of 4 days, daily renewed, and were not exposed to any bleaching treatment.

Groups 3 and 4 were subjected to a bleaching agent based on $38 \%$ hydrogen peroxide, Opalescence Boost PF (Ultradent, South Jordan, UT, USA), applied to the buccal surfaces in a layer approximately $1 \mathrm{~mm}$ in thickness. The gel was left on the substrate for a period of $15 \mathrm{~min}$, after which it was removed with gauze. The application procedure was repeated 2 more times, comprising 1 bleaching session. After 3 days, another bleaching session

Table I. Brand name (manufacturer), classification, composition and batch numbers of materials used in the study.

\begin{tabular}{|c|c|c|c|}
\hline Brand name (manufacturer) & Classification & Composition & Batch numbers \\
\hline Clearfil SE Bond (Kuraray) & $\begin{array}{l}02 \text { steps self- } \\
\text { etching } \\
\text { adhesive system }\end{array}$ & $\begin{array}{l}\text { Primer: MDP, HEMA Camphoroquinone } \\
\text { hydrophylic, dimetha crylate, N.N Dietanol p- } \\
\text { toluidin and water. } \\
\text { Bond: MDP, Bis-GMA, HEMA, hydrophobic } \\
\text { camphoroquinone dimethacrylate N.N- } \\
\text { Dietanol p-toluidine, Sílanized silica. }\end{array}$ & 201949 \\
\hline $\begin{array}{l}\text { Silorane Adhesive } \\
\text { (3M Espe) }\end{array}$ & $\begin{array}{l}02 \text { steps self- } \\
\text { etching } \\
\text { adhesive system }\end{array}$ & $\begin{array}{l}\text { Primer: Phosphated methacrilate, Vitrebond } \\
\text { copolymer, BisGMA, HEMA, water, ethanol } \\
\text { and silinized silica particles. } \\
\text { Bond: Hydrophobic dimetacrylate, } \\
\text { phosphated methacrylate, TEGDMA and } \\
\text { silanized silica particles. }\end{array}$ & $\begin{array}{l}1202700211 \\
1221900749\end{array}$ \\
\hline Filtek Z250 (3M Espe) & $\begin{array}{l}\text { Microhybrid } \\
\text { composite } \\
\text { resin }\end{array}$ & $\begin{array}{l}\text { Aluminum oxide, silica, zirconium oxide, Bis- } \\
\text { GMA/UDMA e } \\
\text { Bis-EMA/TEGDMA }\end{array}$ & 1130100098 \\
\hline Filtek P90 (3M Espe) & $\begin{array}{l}\text { Low shrinkage } \\
\text { microhybrid } \\
\text { composite } \\
\text { resin }\end{array}$ & $\begin{array}{l}\text { Silica/Silane, yttrium trifluoride bis-3, } 4- \\
\text { epoxyciclohexil-etil-fenil-methilsilane, } \\
\text { epoxicyclohexilciclopolimethilsiloxane }\end{array}$ & 1218500237 \\
\hline $\begin{array}{l}\text { Opalescence Boost } \\
\text { PF } 38 \% \text { (Ultradent) }\end{array}$ & $\begin{array}{c}\text { In-office bleaching } \\
\text { agent }\end{array}$ & $38 \%$ hydrogen peroxide & R7QP8 \\
\hline
\end{tabular}


Table II. Division of experimental groups.

\begin{tabular}{llcc}
\hline Group & Bleaching & Adhesive system & Composite resin \\
\hline 1 (control) & No & Clearfil SE Bond & Filtek Z250 \\
2 (control) & No & Silorane Adhesive & Filtek P90 \\
3 & Yes (38\% Hydrogen peroxide) & Clearfil SE Bond & Filtek Z250 \\
4 & Yes (38\% Hydrogen peroxide) & Silorane Adhesive & Filtek P90 \\
\hline
\end{tabular}

was performed. Between sessions, the specimens were stored in artificial saliva at $37^{\circ} \mathrm{C}$. After the second bleaching session, the specimens were kept in artificial saliva for 24 $\mathrm{h}$ until the adhesive bonding procedures were performed.

All groups had the area available for adhesion delimited with an adhesive paper disc containing a $3 \mathrm{~mm}$ in diameter central hole, placed on the enamel surface. The adhesive systems Clearfil SE Bond (Kuraray, Okayama, Japan) and Silorane Adhesive (3M Espe, Seefeld, Germany), both self-etching primers, were applied according to the manufacturers' instructions.

Composite resin cylinders were prepared over the enamel surfaces by adapting the specimens to a split metallic matrix, which formed a $5 \mathrm{~mm}$ in height and 3 $\mathrm{mm}$ in diameter central hole. The composites were inserted in two portions and individually photo-activated for $20 \mathrm{~s}$ and $40 \mathrm{~s}$ for Filtek Z250 and Filtek P90, respectively, using an LED device (Ultra Blue D-2000, DMC, São Carlos, SP, Brazil) with a light intensity of $900 \pm 10 \mathrm{~mW} / \mathrm{cm}^{2}$, as measured by a radiometer.

Immediately after, the specimens were stored in distilled water at $37^{\circ} \mathrm{C}$ for $24 \mathrm{~h}$ until the performance of the shear test, which was conducted with the use of a metallic matrix ribbon $(5 \mathrm{~mm})$ and at a cross-head speed of $0.5 \mathrm{~mm} / \mathrm{min}$. Once the mechanical test was completed, the specimens were placed under a stereo magnifier (40X) for observation of fracture patterns.
After compiling the data, an analysis of variance (two-way ANOVA) and $t$ (LSD) test were performed at a $5 \%$ significance level.

\section{RESULTS}

The mean shear strength values and standard deviations for each group are shown in Table III. Through an analysis of variance (two-way ANOVA), a significant difference was observed among the groups depending on if they were bleached or unbleached (Table IV).

There was a significant reduction in the adhesive bonding strength to enamel adhesive for Filtek Z250 composite resin after tooth bleaching, but the same was not observed with the low-shrinkage Filtek P90 composite (Table V), according to $t$ (LSD) test (5\%).

By comparing the 2 composites tested, a difference in adhesive bonding strength to enamel was observed at both time assessment points (before and after bleaching), with Filtek Z250 composite resin showing significantly higher values (Table VI) according to $t$ (LSD) test (5\%).

Regarding fracture patterns, 36 specimens $(90 \%)$ were classified as adhesive, and $4(10 \%)$ as cohesive in composite resin, observed in groups 2,3 , and 4 .

Table III. Mean and standard deviation of shear bond strengths of experimental groups.

\begin{tabular}{llcccc}
\hline Group & Bleaching & Adhesive System & Composite Resin & $\begin{array}{c}\text { Mean } \\
\text { (MPa) }\end{array}$ & $\begin{array}{c}\text { Standard Deviatior } \\
\text { (MPa) }\end{array}$ \\
\hline G1 & No & Clearfil SE Bond & Filtek Z250 & 4.29 & \pm 1.71 \\
G2 & No & Silorane Adhesive & Filtek P90 & 0.60 & \pm 0.18 \\
G3 & Yes & Clearfil SE Bond & Filtek Z250 & 2.06 & \pm 1.40 \\
G4 & Yes & Silorane Adhesive & Filtek P90 & 0.45 & \pm 0.14 \\
\hline
\end{tabular}

Table IV. Two-way Analysis of Variance (ANOVA) for shear bond strengths (MPa).

\begin{tabular}{llcccc}
\hline Treatment & Df & Sum of Squares & Mean Square & F & p \\
\hline Bleaching & 3 & 95.1015 & 31.700 & 25.5323 & $<0.0001^{*}$ \\
Bonding strategy & 9 & 11.136 & 1.237 & 0.9966 & 0.5334 \\
Error & 27 & 33.523 & 1.242 & & \\
\hline
\end{tabular}

${ }^{*}=$ Significative at $5 \%$. 
Table V. Shear bond strength (mean/MPa) according to the bleaching treatment.

\begin{tabular}{lcccc}
\hline \multirow{2}{*}{ Adhesive System / Composite Resin } & \multicolumn{2}{c}{ Bleaching Treatment } & \multirow{2}{*}{ t } & p \\
\cline { 2 - 3 } & No Bleaching & Bleaching & & \\
\hline Clearfil SE Bond / Filtek Z250 & 4.29 & 2.06 & 4.471 & $<0.001^{*}$ \\
Silorane Adhesive / Filtek P90 & 0.60 & 0.45 & 0.297 & $\mathrm{~ns}$ \\
\hline *=Significative at 5\%; ns= No significant. & & & &
\end{tabular}

Table VI. Mean of shear bond strength (MPa) according to composite resins.

\begin{tabular}{lcccr}
\hline \multirow{2}{*}{ Bleaching Treatment } & \multicolumn{2}{c}{ Adhesive System / Composite Resin } & \multirow{2}{*}{$\mathbf{t}$} & \\
\cline { 2 - 3 } & Clearfil SE Bond / Filtek Z250 & Silorane Adhesive / Filtek P90 & \\
\hline No bleaching & 4.29 & 0.60 & 7.403 & $<0.001^{*}$ \\
Bleaching & 2.06 & 0.45 & 3.229 & $0.0032^{*}$ \\
\hline
\end{tabular}

$*=$ Significative at $5 \%$.

\section{DISCUSSION}

The possible effects of bleaching treatments on bonding procedures to dental substrates have been the subject of constant research. These studies suggest that using hydrogen peroxide concentrations between $25 \%$ and $35 \%$ result in a reduction in the ability of resin materials to adhere to previously bleached substrates, as measured by tensile and shear tests (Attin et al., 2008).

The literature recommends a waiting period between $24 \mathrm{~h}$ up to 3 weeks after bleaching to perform bonding procedures (Attin et al., 2008; Barbosa et al., 2008; Cavalli et al., 2001; Da Silva Machado et al., 2010; Perdigão et al., 1998; Swift \& Perdigão; Unlu et al., 2008; van der Vyver et al., 1997). The main reasons for bonding impairment include a significant reduction in calcium and phosphate levels and morphological changes in the superficial prismatic enamel layer, as well as the possible presence of residual oxygen in the inner part of substrates, which may interfere with the adhesion of composite resins by inhibiting polymerization.

In fact, the subsurface of the enamel organic matrix can be altered by the oxidizing effect of peroxide radicals (Hegedüs et al., 1999; Seghi \& Denry, 1992). These alterations may lead to changes in the mechanical properties of the substrate, such as fracture strength (Hegedüs et al.). Thus, since fracture toughness is an indicator of the ability of enamel to resist crack propagation, changes in this property would cause a decrease in enamel bonding strength. Likewise, morphological changes would result in impaired adhesive bonding resulting from a loss in mineral content and/or increased porosity (Basting et al., 2001; Perdigão et al.).
Such changes in the composition and topography of the enamel seem to be related to factors such as the $\mathrm{pH}$ level, the concentration of acidic components, temperature, time, and frequency of exposure to bleaching agents (Basting et al.; Price et al., 2000).

Still, bleaching agents act by oxidation, allowing the formation and release of oxygen and hydroxyl radicals. These interact chemically with long chains of pigments and turn them into smaller molecules, causing the visual appearance of teeth whitening (Kawamoto \& Tsujimoto, 2004). However, at the end of bleaching therapy, a large amount of residual oxygen may be present in the bleached substrate. The high reactivity of oxygen causes a premature termination of polymer chain formation, compromising the quality of the polymers formed (Rueggeberg \& Margeson, 1990), and decreasing the adhesive bonding strength of resin materials to the tooth structure (da Silva et al., 2010; Sasaki et al., 2009).

The reasons listed above may explain the results obtained with the Clearfil SE Bond adhesive system and the Filtek Z250 composite in this study, where performance of a bleaching treatment with high-concentration hydrogen peroxide (38\%) significantly reduced the levels of bonding strength to enamel.

On the other hand, while oxidizing compounds used as bleaching agents are able to inhibit free radicalled polymerization of most resin monomers through oxygen release (Tezvergil-Mutluay et al., 2008), the curing reaction by cationic ring opening, which is associated with the presence of oxirane in silorane-based 
MONTEIRO, T. L.; CARNEIRO, N. C. M.; NOGUEIRA, B. C. L.; BRAGA, E. M. F.; SOUZA JÚNIOR, M. H. S. \& LORETTO, S. C. Influence of tooth bleaching on the bonding strength of silorane-based restorative system. Int. J. Odontostomat., 9(3):497-504, 2015.

dental composites, seems to be insensitive to oxygen (Ilie \& Hickel, 2009; Shawkat et al., 2009; TezvergilMutluay et al.), which could be considered advantageous during adhesion to bleached substrates.

The adhesive system of low shrinkage (silorane) composite resins differs from other 2-step self-etching agents because the self-etching primer requires polymerization (Magni et al., 2008; Navarra et al., 2009), which differentiates it from other methacrylate-based bonding agents (Grégoire et al., 2010; Mine et al., 2010). Navarra et al. showed a higher degree of conversion of silorane adhesive in the hybrid layer than in the Clearfil SE Bond system, which is a fundamental prerequisite for the stability of the adhesive bond.

These explanations may support the results of this study, in which the bonding of the low-shrinkage composite Filtek P90, and its respective adhesive system, were not influenced by prior bleaching with $38 \%$ hydrogen peroxide. This finding differs from that of CanKarabulut and Karabulut (Can-Karabulut \& Karabulut, 2011), in which the adhesive strength of low-shrinkage composite resins showed to be sensitive to prior exposure to the same bleaching agent, although in that study peroxide gel was activated by a diode laser during bleaching.

Furthermore, attention should be called to the significantly lower bond strength values obtained with the silorane-based composite Filtek P90 compared to the methacrylate-based composite resin Filtek Z250, regardless of prior bleaching. This result can be attributed, in part, to the chemical differences between the 2 composites.

Guiraldo et al. (2010) demonstrated that a difference in light transmission between silorane and methacrylate-based resin composites does exist, with the latter having a significantly higher degree of subsurface polymerization. Moreover, the depth of curing and degree of conversion were statistically lower in the low-shrinkage (silorane) composites than in the conventional (methacrylate) composites (Kusgoz et al., 2011). Thus, as the polymerization of the subsurface is related to adhesive bonding strength (Kim et al., 2006), lower values can be expected with low-shrinkage resins (Guiraldo et al.).

The composition of restorative resins also plays a major role in bonding strength to dental substrates. Miyazaki et al. (1991) demonstrated that bonding strength is enhanced with the increased filler content of composites. The composite resin Filtek P90 has a $76 \%$ of inorganic content by weight, whereas Filtek Z250 has $82 \%$, which might also explain the results of this study.

Likewise, different photo-activating light sources can influence the strength of the adhesive bond to dental substrates. In a previous study, Khosla et al. (2012) showed that the silorane-based composite Filtek P90 had a lower bond strength when photo-activated with an LED-type device compared to activation with a halogen quartz-tungsten lamp.

In the composite resin Filtek P90, one of the photo-initiators is camphorquinone, which is sensitized in the light spectrum of conventional light sources. Still, in the reaction, an electron donor acts in a process of oxidation-reduction, decomposing iodine salts in acidic cations, and initiating the polymerization process by cationic ring opening. Thus, it is assumed that the narrow light spectrum of LED-type devices, as used in this study, may not fully activate these multiple initiators on silorane-based composites (Khosla et al.), justifying the lower bonding strength values found in this restorative system.

Still, it has been shown that higher values ??of bonding strength to enamel with the silorane adhesive system are obtained when pre-etching with phosphoric acid is performed, a step which was not carried out in this study. It is believed that the adhesive can penetrate deeper into the intra- and inter-prismatic spaces of the conditioned enamel, improving the performance of the bonding agent and preventing the occurrence of mechanical pretest failures (Duarte et al., 2009), which were common in our research with the Filtek P90 composite.

Finally, one methodological issue deserves to be highlighted: although shear tests represent a commonly used laboratory assessment of the strength of adhesive interfaces (Burke et al., 2008), there has been critiques on its design, as it allows the shearing load to be easily transformed into bending and cleavage forces, generating a non-uniform distribution of tension across the bonding interface and, therefore, compromising the results obtained in terms of a faithful assessment of the strength in the bonding area (DeHoff et al., 1995; Sudsangiam \& van Noort, 1991).

These remarks are found with regard to the shear test using a chisel. Thus, considering these limitations, a mechanical test with a metallic ribbon was 
chosen, since this would more faithfully allow sliding (shearing) between the enamel surfaces and the composite resin (Braz et al., 2012; Sinhoreti et al., 2001).

Moreover, the low numerical values of bonding strength, as were found in the present study, are typical of shear testing performed with a metal ribbon. If these values are compared with those from similar studies that have used another apparatus during the test (e.g., a chisel), caution should be exercised in drawing conclusions regarding the performance of a given material (Sinhoreti et al.).

Because of conflicting data in the literature, it is clear that some doubts still remain regarding the performance of restorative procedures after the application of bleaching techniques. Therefore, investigation into the occurrence of these laboratory findings in clinical practice is of fundamental importance, given the small amount of information available at this level of assessment.

In conclusion, tooth bleaching significantly reduced the adhesive bonding strength of a methacrylate-based restorative system (Filtek Z250) to enamel, whereas the same was not observed with a silorane-based restorative system (Filtek P90). The adhesive bonding strength to enamel, regardless of performance of a bleaching treatment, was significantly lower with the silorane-based restorative system (Filtek P90).

MONTEIRO, T. L.; CARNEIRO, N. C. M.; NOGUEIRA, B. C. L.; BRAGA, E. M. F.; SOUZA JÚNIOR, M. H. S. \& LORETTO, S. C. Influencia del aclaramiento dental en la fuerza de adhesion del sistema restaurativo a base de silorano. Int. J. Odontostomat., 9(3):497-504, 2015.

RESUMEN: Los procedimientos de blanqueamiento dental pueden interferir en la unión adhesiva de los materiales de restauración a base de metacrilato. Después de la introducción de materiales compuestos a base de silorano, hay poca información disponible acerca de esta interacción. El objetivo fue evaluar la influencia del blanqueamiento en la cizalladura de la fuerza de adhesion sobre esmalte del sistema restaurativo a base de silorano. Cuarenta dientes incisivos bovinos fueron divididos aleatoriamente en 4 grupos $(n=10)$, siendo: $G 1$ (control) - no aclarado + Clearfil SE Bond (CSEB)/Filtek Z250 ( 2250$)$, G2 (control) - no aclarado + adhesivo de silorane (AS)/Filtek P90 (P90), G3 - aclarado + CSEB / Z250; g4 - aclarado + AS/P90. Los dientes fueron seccionados, tenían coronas incluidas en anillos de pvc, y las superficies de esmalte fueron molidas y pulidas con papeles abrasivos de silicona de silicio. G1 y G2 fueron almacenados en saliva artificial $\left(37^{\circ} \mathrm{C}\right)$, renovada diariamente, durante un período de 04 días. G3 y G4 se expusieron a 2 sesiones de peróxido de hidrógeno al $38 \%$ ( 38 HP) con 03 aplicaciones de 15 min en cada sesión. Los cilindros de resina compuesta fueron construidos en las superficies de esmalte. Los procedimientos de unión se realizaron según las instrucciones del fabricante. Después del almacenamiento en agua destilada durante $24 \mathrm{~h}\left(37^{\circ} \mathrm{C}\right)$, las muestras fueron sometidas al ensayo de resistencia de adhesión al cizallamiento. Los datos fueron analizados por ANOVA de dos vías y prueba t (5\%). La comparación intragrupo mostró diferencias significativas para Z250 después del aclaramiento, pero no para P90. La resistencia al corte fue significativamente menor para P90, a pesar de los procedimientos de blanqueamiento. En conclusión, el blanqueamiento con $38 \mathrm{HP}$ no tuvo influencia en la resistencia de la unión esmalte de P90, a pesar de presentar una fuerza de unión más baja que Z250.

PALABRAS CLAVE: blanqueamiento dental, resinas compuestas, resistencia a la cizalladura.

\section{REFERENCES}

Amaral, C.; Jorge, A.; Veloso, K.; Erhardt, M.; Arias, V. \& Rodrigues, J. A. The effect of in-office in combination with intracoronal bleaching on enamel and dentin bond strength and dentin morphology. J. Contemp. Dent. Pract., 9(5):17-24, 2008.

Attin, T.; Hannig, C.; Wiegand, A. \& Attin, R. Effect of bleaching on restorative materials and restorations--a systematic review. Dent. Mater., 20(9):852-61, 2004.

Barbosa, C. M.; Sasaki, R. T.; Florio F. M. \& Basting, R. T. Influence of time on bond strength after bleaching with
$35 \%$ hydrogen peroxide. J. Contemp. Dent. Pract., 9(2):81-8, 2008.

Basting, R. T.; Rodrigues Júnior, A. L. \& Serra, M. C. The effect of $10 \%$ carbamide peroxide bleaching material on microhardness of sound and demineralized enamel and dentin in situ. Oper. Dent., 26(6):531-9, 2001.

Braz, R.; Cordeiro-Loretto, S.; de Castro-Lyra, A. M.; Dantas, D. C.; Ribeiro, A. I.; Guênes, G. M. \& LeiteCavalcanti, A. Effect of bleaching on shear bond strength to dentin of etch-and-rinse and self-etching 
primer adhesives. Acta Odontol. Latinoam., 25(1):206, 2012.

Burgess, J. \& Cakir, D. Comparative properties of lowshrinkage composite resins. Compend. Contin. Educ. Dent., 31(Spec. No.2):10-5, 2010.

Burke, F. J.; Hussain, A.; Nolan, L. \& Fleming, G. J. Methods used in dentine bonding tests: an analysis of 102 investigations on bond strength. Eur. J. Prosthodont. Restor. Dent., 16(4):158-65, 2008.

Can-Karabulut, D. C. \& Karabulut, B. Influence of activated bleaching on various adhesive restorative systems. $J$. Esthet. Restor. Dent., 23(6):399-408, 2011.

Cavalli, V.; Reis, A. F.; Giannini, M. \& Ambrosano, G. M. The effect of elapsed time following bleaching on enamel bond strength of resin composite. Oper. Dent., 26(6):597-602, 2001.

da Silva, A. P.; Lima, A. F.; Cavalcanti, A. N. \& Marchi, G. $M$. Effects of $3 \%$ sodium ascorbyl phosphate on the hardness and bond strength of human enamel bleached with $10 \%$ carbamide peroxide. Gen. Dent., 58(4):e1748, 2010.

Da Silva Machado, J.; Cândido, M. S.; Sundfeld, R. H.; De Alexandre, R. S.; Cardoso, J. D. \& Sundefeld, M. L. The influence of time interval between bleaching and enamel bonding. J. Esthet. Restor. Dent., 19(2):111-8, 2007.

DeHoff, P. H.; Anusavice, K. J. \& Wang, Z. Three-dimensional finite element analysis of the shear bond test. Dent. Mater., 11(2):126-31, 1995.

Duarte, S. Jr.; Botta, A. C.; Phark, J. H. \& Sadan, A. Selected mechanical and physical properties and clinical application of a new low-shrinkage composite restoration. Quintessence Int., 40(8):6318, 2009.

Guiraldo, R. D.; Consani, S.; Consani, R. L.; Berger, S. B.; Mendes, W. B.; Sinhoreti, M. A. \& Correr-Sobrinho, L. Comparison of silorane and methacrylate-based composite resins on the curing light transmission. Braz. Dent. J., 21(6):538-42, 2010.

Grégoire, G.; Dabsie, F.; Delannée, M.; Akon, B. \& Sharrock P. Water permeability, hybrid layer long-term integrity and reaction mechanism of a two-step adhesive system. J. Dent., 38(7):526-33, 2010.

Hegedüs, C.; Bistey, T.; Flóra-Nagy, E.; Keszthelyi, G. \& Jenei, A. An atomic force microscopy study on the effect of bleaching agents on enamel surface. J. Dent., 27(7):509-15, 1999.
Hussain, M. \& Wang, Y. Influence of prolonged light-curing time on the shear bonding strength of resin to bleached enamel. Oper. Dent., 35(6):672-81, 2010.

Ilie, N. \& Hickel, R. Silorane-based dental composite: behavior and abilities. Dent. Mater. J., 25(3):445-54, 2006.

Ilie, N. \& Hickel, R. Macro-, micro- and nano-mechanical investigations on silorane and methacrylate-based composites. Dent. Mater., 25(6):810-9, 2009.

Kawamoto, K. \& Tsujimoto, Y. Effects of the hydroxyl radical and hydrogen peroxide on tooth bleaching. $J$. Endod., 30(1):45-50, 2004.

Khosla, M.; Malhotra, N. \& Mala, K. An in vitro evaluation of shear bond strength of silorane and bis-GMA resinbased composite using different curing units. J. Conserv. Dent., 15(3):278-82, 2012.

Kim, J. S.; Choi, Y. H.; Cho, B. H.; Son, H. H.; Lee, I. B.; Um, C. M. \& Kim, C. K. Effect of light-cure time of adhesive resin on the thickness of the oxygen-inhibited layer and the microtensile bond strength to dentin. J. Biomed. Mater. Res. B Appl. Biomater., 78(1):115-23, 2006.

Kusgoz, A.; Ülker, M.; Yesilyurt, C.; Yoldas, O. H.; Ozil, M. \& Tanriver M. Silorane-based composite: depth of cure, surface hardness, degree of conversion, and cervical microleakage in Class II cavities. J. Esthet. Restor. Dent., 23(5):324-35, 2011.

Lima, A. F.; Sasaki, R. T.; Araújo, L. S.; Gaglianone, L. A.; Freitas, M. S.; Aguiar, F. H. \& Marchi, G. M. Effect of tooth bleaching on bond strength of enamel-dentin cavities restored with silorane- and dimethacrylatebased materials. Oper. Dent., 36(4):390-6, 2011.

Magni, E.; Ferrari, M.; Hickel, R.; Huth, K. C. \& Ilie, N. Effect of ozone gas application on the mechanical properties of dental adhesives bonded to dentin. Dent. Mater., 24(10):1428-34, 2008.

Mine, A.; De Munck, J.; Van Ende, A.; Cardoso, M. V.; Kuboki, T.; Yoshida, Y. \& Van Meerbeek, B. TEM characterization of a silorane composite bonded to enamel/dentin. Dent. Mater., 26(6):524-32, 2010.

Miyazaki, M.; Hinoura, K.; Onose, H. \& Moore, B. K. Effect of filler content of light-cured composites on bond strength to bovine dentine. J. Dent., 19(5):301-3, 1991.

Navarra, C. O.; Cadenaro, M.; Armstrong, S. R.; Jessop, J.; Antoniolli, F.; Sergo, V.; Di Lenarda, R. \& Breschi, L. Degree of conversion of Filtek Silorane Adhesive System and Clearfil SE Bond within the hybrid and 
adhesive layer: an in situ Raman analysis. Dent. Mater., 25(9):1178-85, 2009.

Nour El-din, A. K.; Miller, B. H.; Griggs, J. A. \& Wakefield, C. Immediate bonding to bleached enamel. Oper. Dent., 31(1):106-14, 2006.

Perdigão, J.; Francci, C.; Swift, E. J. Jr.; Ambrose, W. W. \& Lopes, M. Ultra-morphological study of the interaction of dental adhesives with carbamide peroxide-bleached enamel. Am. J. Dent., 11(6):291-301, 1998.

Price, R. B.; Sedarous, M. \& Hiltz, G. S. The pH of toothwhitening products. J. Can. Dent. Assoc., 66(8):421-6, 2000.

Rueggeberg, F. A. \& Margeson, D. H. The effect of oxygen inhibition on an unfilled/filled composite system. J. Dent. Res., 69(10):1652-8, 1990.

Sasaki, R. T.; FI Rio, F. M. \& Basting, R. T. Effect of $10 \%$ Sodium Ascorbate and 10\% ?-tocopherol in Different Formulations on the Shear Bond Strength of Enamel and Dentin Submitted to a Home-use Bleaching Treatment. Oper. Dent., 34(6):746-52, 2009.

Seghi, R. R. \& Denry, I. Effects of external bleaching on indentation and abrasion characteristics of human enamel in vitro. J. Dent. Res., 71(6):1340-4, 1992.

Shawkat, E. S.; Shortall, A. C.; Addison, O. \& Palin W. M. Oxygen inhibition and incremental layer bond strengths of resin composites. Dent. Mater., 25(11):1338-46, 2009.

Sinhoreti, M. A.; Consani, S.; De Goes, M. F.; Sobrinho, L. C. \& Knowles, J. C. Influence of loading types on the shear strength of the dentin-resin interface bonding. $J$. Mater. Sci.: Mater. Med., 12(1):39-44, 2001.

Sudsangiam, S. \& van Noort, R. Do dentin bond strength tests serve a useful purpose? J. Adhes. Dent., 1(1):5767. 1999.

Swift, E. J. Jr. \& Perdigão, J. Effects of bleaching on teeth and restorations. Compend. Contin. Educ. Dent., 19(8):815-20, 1998.

Tezvergil-Mutluay, A.; Lassila, L. V. \& Vallittu, P. K. Incremental layers bonding of silorane composite: the initial bonding properties. J. Dent., 36(7):560-3, 2008.

Unlu, N.; Cobankara, F. K. \& Ozer, F. Effect of elapsed time following bleaching on the shear bond strength of composite resin to enamel. J. Biomed. Mater. Res. B Appl. Biomater., 84(2):363-8, 2008.

van der Vyver, P. J.; Lewis, S. B. \& Marais, J. T. The effect of bleaching agent on composite/enamel bonding. J. Dent. Assoc. S. Afr., 52(10):601-3, 1997.
Weinmann, W.; Thalacker, C. \& Guggenberger, R. Siloranes in dental composites. Dent. Mater., 21(1):68-74, 2005.

Correspondence to:

Sandro Cordeiro Loretto

Avenida Conselheiro Furtado, 2312

Oásis, apto. 401

CEP: 66040-100 -Belém

Pará

BRAZIL

Email: sandroloretto@hotmail.com

Received: 21-08-2015

Accepted: 09-11-2015 